KOMPARTEMEN: JURNAL ILMIAH AKUNTANSI

September 2020, Volume XIX, No 2, 99-109

\title{
PENGARUH PROFITABILITAS, KEPEMILIKAN INSTITUSIONAL DAN KINERJA LINGKUNGAN TERHADAP ISLAMIC SOCIAL REPORTING
}

\author{
Afriana Dwi Widyanti ${ }^{1}$, Nadia Cilarisinta ${ }^{2}$ \\ Universitas Muhammadiyah Purwokerto ${ }^{1,2}$
}

\begin{abstract}
This study was conducted to examine the effect of profitability, institutional ownership, and environmental performance on the disclosure of Islamic Social Reporting (ISR) on Islamic banking in Indonesia. The samples used are Sharia Commercial Banks in Indonesia which published annual reports from the 20162018. The technique to test the hypothesis is multiple linear regression analysis. The results shown that profitability, and environmental performance have not affect on the disclosure of ISR. Institutional ownership has affect on the disclosure of Islamic Social Reporting (ISR).
\end{abstract}

Keywords: Islamic social reporting; profitability; institutional ownership; environmental performance

\begin{abstract}
ABSTRAK
Penelitian ini dilakukan untuk menguji pengaruh profitabilitas, kepemilikan institusional, dan kinerja lingkungan terhadap pengungkapan Islamic Social Reporting (ISR) pada perbankan syariah di Indonesia. Sampel yang digunakan adalah Bank Umum Syariah di Indonesia yang menerbitkan laporan tahunan dari periode 2016-2018. Teknik untuk menguji hipotesis adalah analisis regresi linear berganda. Hasil pengujian menunjukkan bahwa profitabilitas dan kinerja lingkungan tidak berpengaruh terhadap Islamic Social Reporting (ISR). Kepemilikan institusional berpengaruh terhadap pengungkapan Islamic Social Reporting (ISR).
\end{abstract}

Kata kunci: Islamic social reporting; profitabilitas; kepemilikan institusional; kinerja lingkungan.

\section{PENDAHULUAN}

Terkait dengan adanya kebutuhan mengenai pengungkapan tanggung jawab social di sektor syariah atau yang dikenal Islamic Social Reporting (ISR). Accounting and Auditing Organization for Islamic Financial Institutions (AAOIFI) yang merupakan organisasi internasional yang berwewenang dalam penetapan standar akuntansi, audit, tata kelola, dan etika syariah untuk institusi keuangan syariah di dunia telah menetapkan item-item Islamic Social Reporting, yang kemudian dikembangkan lebih lanjut oleh para peneliti (Haniffa, 2002; Farook dan Lanis, 2005; Dusuki, 2005; Maali et al, 2006; dan Othman et al, 2009).

99 http://jurnalnasional.ump.ac.id/index.php/kompartemen/


Indeks $I S R$ merupakan tolak ukur pelaksanaan kinerja social perbankan syariah yang berisi kompilasi item-item standar CSR yang ditetapkan oleh Accounting and Auditing Organization for Islamic Financial Institutions (AAOIFI) yang kemudian dikembangkan lebih lanjut oleh para peneliti mengenai item-item CSR yang seharusnya diungkapkan oleh suatu entitas Islam (Othman et al, 2010).

Berkembangnya ISR di Indonesia turut meningkatkan perhatian masyarakat terhadap lembaga atau institusi syariah. Maulida dkk (2014) menyatakan bahwa pelaksanaan ISR masih berorientasi di sektor perbankan syariah saja. Pelaksanaan ISR pada sektor non perbankan dan lembaga keuangan lainnya belum banyak diteliti sehingga pelaksanaan konsep ISR terutama di Indonesia masih kurang meluas.

\section{TINJAUAN LITERATUR DAN PENGEMBANGAN HIPOTESIS}

Dalam penelitian ini menggunakan tiga teori, yaitu teori keagenan, teori legitimasi, dan teori stakeholder. Teori keagenan mengungkapkan adanya hubungan antara principal (pemilik perusahaan atau pihak yang memberikan mandat, sering disebut dengan investor/pemegang saham) dan agent (manajer perusahaan atau pihak yang menerima mandat/manajemen) yang dilandasi dari adanya pemisahan kepemilikan dan pengendalian perusahaan, pemisahan penanggung resiko, pembuatan keputusan dan pengendalian fungsi-fungsi (Jensen and Meckling, 1976).

Teori legitimasi, menjelaskan bahwa perusahaan akan melakukan aktivitas CSR disebabkan adanya tekanan sosial, politik dan ekonomi dari luar perusahaan. Sehingga perusahaan akan menyeimbangkan tuntutan tersebut dengan melakukan apa yang diinginkan oleh masyarakat dan apa yang diharuskan oleh peraturan. Teori ini mengungkapkan bahwa perusahaan secara kontinyu berusaha untuk bertindak sesuai dengan batas-batas dan norma-norma dalam masyarakat. Atas usahanya tersebut perusahaan berusaha agar aktivitasnya diterima menurut persepsi pihak eksternal (Deegan, 2000).

Teori stakeholder secara luas dijelaskan bahwa sebagai setiap kelompok atau individu yang dapat mempengaruhi atau dipengaruhi oleh operasi dan kegiatan perusahaan (Freeman, 1984). Eden dan Ackerman (1998) menyatakan bahwa stakeholder yaitu hanya orang atau kelompok yang memiliki kekuatan untuk secara langsung memengaruhi masa depan organisasi, dengan tidak adanya kekuatan itu mereka tidak dianggap sebagai stakeholder.

\section{Profitabilitas}

Profitabilitas dapat diproksikan dengan Return on Asset (ROA). ROA adalah rasio yang menunjukkan perbandingan antara laba (sebelum pajak) dengan rata-rata aset. Rasio ini menunjukkan tingkat efisiensi pengelolaan aset yang dilakukan oleh bank bersangkutan (Khairunnisa, 2010). Menurut Watts dan Zimmerman (1986), perusahaan dengan profit yang lebih tinggi memiliki kecenderungan untuk melakukan intervensi kebijakan, termasuk dalam

pengungkapan tanggungjawab sosial. Lestari (2013), Raditya (2012) dan Othman et al. (2009) menunjukkan adanya pengaruh positif antara ROA terhadap pengungkapan ISR. ROA yang 
semakin tinggi maka semakin luas pula pengungkapan ISR perbankan syariah, sehingga rumusan hipotesis 1 sebagai berikut:

H1: Profitabilitas berpengaruh positif terhadap pengungkapan ISR.

\section{Kepemilikan Institusional}

Perusahaan dengan kepemilikan institusional yang besar lebih mampu untuk memonitor kinerja manajemen. Investor institusional memiliki power dan experience serta bertanggung jawab dalam menerapkan prinsip good corporate governance untuk melindungi hak dan kepentingan seluruh penegang saham. Mereka menuntut perusahaan untuk melakukan komunikasi secara transparan. Dengan demikian, kepemilikan institusional dapat meningkatkan kualitas dan kuantitas pengungkapan secara sukarela. Kepemilikan institusional dapat mendorong perusahaan untuk meningkatkan pengungkapan tanggung jawab sosial dan lingkungan (Hariyanti, 2012). Murwaningsari (2009) menyatakan bahwa kepemilikan institusional dengan kepemilikan saham yang besar, memiliki insentif untuk memantau pengambilan keputusan perusahaan. Apabila dikaitkan dengan pengungkapan tanggung jawab sosial, aktivitas monitoring yang dilakukan oleh investor institusi dapat memaksa manajemen untuk mengungkapkan informasi sosialnya.

H2: Kepemilikan institusional berpengaruh terhadap pengungkapan ISR

\section{Kinerja Lingkungan}

Kinerja lingkungan merupakan kinerja perusahaan yang menunjukkan kepedulian dalam menghasilkan lingkungan yang baik. Kinerja lingkungan dapat diukur menggunakan indeks GRI 3.1. Indeks ini dikeluarkan oleh Global Reporting Initiative yang terdiri dari tujuh indikator (ekonomi, lingkungan, praktik tenaga kerja, hak asasi manusia, kemasyarakatan, kewajiban produk, dan indeks khusus keuangan) dan memiliki 100 item. Setiap item yang terdapat pada laporan tahunan diberi nilai 1 dan item yang tidak terdapat pada laporan tahunan diberi nilai 0 . Variabel pengungkapan tanggung jawab sosial diukur dengan cara membagi jumlah skor item yang digunakan dengan jumlah skor maksimum pada masing-masing indeks.

H3: Kinerja lingkungan berpengaruh terhadap pengungkapan ISR.

\section{Islamic Social Reporting}

Islamic social reporting merupakan perluasan dari pelaporan sosial yang tidak hanya berupa keinginan besar dari seluruh masyarakat terhadap peranan perusahaan dalam ekonomi melainkan berkaitan dengan perspektif spiritual (Haniffa, 2002). Kini ISR memiliki tema pengungkapan yaitu terdiri dari enam tema antara lain:

1. Pendanaan dan investasi (finance \& investment)

Item yang termasuk dalam indikator investasi dan keuangan adalah mengenai sumber dana untuk aktivitas investasi dan pembiayaan yang terbebas dari unsur riba, gharar, dan transaksi yang diharamkan oleh Islam, serta item mengenai kebijakan organisasi untuk menangani nasabah yang bermasalah. 
2. Produk dan jasa

Item ISR yang mengenai produk dan jasa menyangkut masalah lingkungan yang merupakan pengungkapan terhadap adanya keluhan dari nasabah.

3. Karyawan

Pada indeks ISR item-tem indikator ini tetap menekankan pada prisip-prinsip Islam yang meliputi karakteristik pekerja, pendidikan dan pelatihan dan persamaan kesempatan.

4. Masyarakat

Item masyarakat ini merupakan item yang sangat erat hubunganya dengan konsep tanggung jawab sosial. Item ini difokuskan pada pengungkapan yang terkait dengan prinsip-prinsip Islam seperti soddaqoh, waqaf, qard hassan, serta kegiatan amal lainnya.

5. Lingkungan

Item ini berkaitan dalam menekankan pada prinsip keseimbangan, kesederhanaan, dan tanggung jawab dalam menjaga lingkungan.

6. Tata Kelola Organisasi

Tata kelola organisasi merupakan item yang terakhir dalam pengungkapan indeks ISR yang merupakan seluruh pengungkapan yang terkait dengan adanya transaksi haram.

\section{METODE PENELITIAN}

Populasi yang digunakan dalam penelitian ini adalah seluruh bank umum syariah yang ada di Indonesia. Adapun teknik pengambilan sampel menggunakan metode purposive sampling, yaitu bank umum syariah yang menerbitkan laporan tahunan 2016-2018. Jenis data yang digunakan merupakan data sekunder yang berasal dari laporan keuangan tahunan. Teknik pengumpulan data dalam penelitian ini dilakukan dengan metode studi dokumentasi. Metode analisis menggunakan regresi linier berganda. Model regresi berganda harus memenuhi uji asumsi klasik, yang meliputi uji normalitas, multikolinearitas, heterokedastisitas, dan autokorelasi. Dan pengujian hipotesis menggunakan uji t.

\section{Definisi Operasional dan Pengukuran Variabel \\ Pengungkapan Islamic Social Reporting}

Indeks Islamic Social Reporting digunakan untuk mengetahui tingkat pengungkapan Islamic Social Reporting di dalam laporan tahunan bank umum syariah. Indeks yang digunakan merujuk pada Haniffa (2002) dan dimodifikasi dengan item-item pengungkapan pada penelitian Othman et al. (2009). Masing-masing item pengungkapan memiliki skor 1 atau 0. Skor 1 diberikan apabila item Islamic Social Reporting dilakukan perusahaan dan skor 0 apabila item Islamic Social Reporting tidak dilakukan.

Indeks Islamic Social Reporting Disclosure (ISRD) adalah perbandingan antara pengungkapan Islamic Social Reporting yang sudah dilakukan oleh perusahaan dengan jumlah maksimum pengungkapan Islamic Social Reporting harus diungkapkan oleh perusahaan. Dengan demikian, formula ISRD adalah sebagai berikut:

$$
\text { ISRD }_{=} \frac{\text { Jumlah Skor Diclosure Yang Terpenuhi }}{\text { Jumlah Skor Disclosure Maksimum }}
$$




\section{Profitabilitas}

Rasio profitabilitas menunjukkan kemampuan suatu perusahaan untuk memperoleh keuntungan (profit). Profitabilitas dalam penelitian ini diukur dengan menggunakan rasio Return on Assets (ROA). ROA sebagai proksi dari profitabilitas yang sejalan dengan penelitian Raditya (2012), yaitu dengan cara membandingkan laba setelah pajak dengan total aset perusahaan sebagai berikut:

$$
\text { ROA }=\frac{\text { Laba Setelah Pajak }}{\text { Total Aset }}
$$

\section{Kepemilikan Institusional}

Kepemilikan institusional yaitu jumlah saham yang dimiliki oleh suatu institusi dalam perusahaan. Kepemilikan institusional diukur dengan presentase jumlah saham milik institusi terhadap jumlah saham yang beredar dalam perusahaan (Hastuti, 2011).

\section{Kinerja Lingkungan}

Kinerja lingkungan diukur menggunakan indeks GRI 3.1 yang dikeluarkan oleh Global Reporting Initiative yang terdiri dari tujuh indikator (ekonomi, lingkungan, praktik tenaga kerja, hak asasi manusia, kemasyarakatan, kewajiban produk, dan indeks khusus keuangan) dan memiliki 100 item. Setiap item yang terdapat pada laporan tahunan diberi nilai 1 dan item yang tidak terdapat pada laporan tahunan diberi nilai 0. Pengungkapan tanggung jawab sosial diukur dengan cara membagi jumlah skor item yang digunakan dengan jumlah skor maksimum.

\section{HASIL PENELITIAN DAN DISKUSI}

\section{Statistik Deskriptif}

Statistik deskriptif digunakan untuk memberikan gambaran atau deskripsi mengenai karakteristik variabel yang diamati. Jumlah sampel yang digunakan dalam penelitian ini sebanyak 33 data observasi yang diambil dengan metode purposive sampling dan telah memenuhi kriteria sampel sesuai dengan variabel yang dibutuhkan.

Table 1. Statistik Deskriptif

\begin{tabular}{|l|r|r|r|r|}
\hline \multicolumn{1}{|c|}{ Variabel } & \multicolumn{1}{c|}{ Minimum } & Maximum & \multicolumn{1}{c|}{ Mean } & \multicolumn{1}{c|}{ Std. Deviation } \\
\hline Profitabilitas & -0.1122749 & 0.0557288 & 0.005312910 & 0.0243879520 \\
\hline Kepemilikan Institusional & 82.94 & 100.00 & 97.6258 & 4.59682 \\
\hline Kinerja Lingkungan & 0.3690476 & 0.7500000 & 0.539321789 & 0.1037613223 \\
\hline ISR & 0.5581395 & 0.7209302 & 0.642706131 & 0.0460801872 \\
\hline
\end{tabular}

Berdasarkan tabel 1, pengungkapan ISR menunjukkan nilai rata-rata sebesar 0,6427. Hal ini berarti bahwa rata-rata perusahaan sampel telah mengungkapkan $64,27 \%$ dari total pengungkapan. Perusahaan yang paling lengkap melaporkan tanggung jawab sosial yaitu sebesar $72,09 \%$. Perusahaan yang paling sedikit melaporkan tanggung jawab sosial sebesar $55,81 \%$. 


\section{Uji Normalitas}

Tabel 2. Hasil uji normalitas

\begin{tabular}{|l|l|r|}
\hline \multicolumn{2}{|l|}{} & Unstandardized Residual \\
\hline $\mathrm{N}$ & 33 \\
\hline Normal Parameters & Mean & 0.0000000 \\
\cline { 2 - 3 } & Std. Deviation & 0.04179194 \\
\hline \multirow{2}{*}{$\begin{array}{l}\text { Most Extreme } \\
\text { Differences }\end{array}$} & Absolute & 0.109 \\
\cline { 2 - 3 } & Positive & 0.109 \\
\cline { 2 - 3 } & Negative & -0.101 \\
\hline Test Statistic & 0.109 \\
\hline Asymp. Sig. (2-tailed) & $0.200^{\mathrm{c}, \mathrm{d}}$ \\
\hline
\end{tabular}

Uji normalitas dilakukan dengan menggunakan pengujian one sample Kolmogorov Smirnov. Hasil pengujian menunjukkan bahwa data telah berdistribusi normal (nilai asymptotic significance sebesar $0,2>0,05)$.

\section{Uji Multikolinieritas}

Tabel 3. Hasil uji multikolinieritas

\begin{tabular}{||l|r|c|}
\hline \multirow{2}{*}{\multicolumn{1}{|c|}{ Variabel }} & \multicolumn{2}{c|}{ Collinearity Statistics } \\
\cline { 2 - 3 } & Tolerance & \multicolumn{1}{c|}{ VIF } \\
\hline Profitabilitas & 0.601 & 1.664 \\
\hline Kepemilikan Institusional & 0.604 & 1.654 \\
\hline Kinerja Lingkungan & 0.978 & 1.023 \\
\hline
\end{tabular}

Uji multikolinearitas digunakan untuk mengetahui ada atau tidaknya hubungan linear antar variabel independen dalam model regresi (Sujarweni, 2014). Model dinyatakan terbebas dari gangguan multikolinearitas jika mempunyai nilai VIF dibawah 10 atau tolerance diatas 0,1 .

\section{Uji Heterokedastisitas}

Tabel 4. Hasil uji heteroskedastisitas

\begin{tabular}{|l|c|c|c|c|c|}
\hline \multirow{2}{*}{\multicolumn{1}{|c|}{ Variabel }} & \multicolumn{2}{|c|}{ Unstandardized Coefficients } & Standardized Coefficients & \multirow{2}{*}{$\mathrm{t}$} & \multirow{2}{*}{ Sig. } \\
\cline { 2 - 4 } & $\mathrm{B}$ & Std. Error & Beta & & \\
\hline (Constant) & -0.034 & 0.095 & & -0.362 & 0.720 \\
\hline Profitabilitas & 0.243 & 0.187 & 0.283 & 1.304 & 0.203 \\
\hline Kepemilikan Institusional & 0.000 & 0.001 & 0.088 & 0.406 & 0.688 \\
\hline Kinerja Lingkungan & 0.055 & 0.034 & 0.272 & 1.601 & 0.120 \\
\hline
\end{tabular}

Berdasarkan tabel 4. diketahui bahwa nilai sig. variabel profitabilitas, kepemilikan institusional dan kinerja lingkungan $>0,05$. Hal ini dapat dinyatakan bahwa data tersebut tidak terjadi heteroskedastisitas dalam model penelitian ini. 


\section{Uji Autokorelasi}

\section{Tabel 5. Hasil uji autokorelasi}

\begin{tabular}{|l|c|r|r|r|r|}
\hline Model & $\mathbf{R}$ & R Square & Adjusted R Square & Std. Error & Durbin-Watson \\
\hline 1 & $0.421^{\mathrm{a}}$ & 0.177 & 0.092 & 0.043900406 & 2.083 \\
\hline
\end{tabular}

Dalam penelitian ini, uji autokorelasi dilakukan dengan menggunakan statistik Durbin Watson. Hasil pengujian menunjukkan nilai DW sebesar 2,083. Nilai du dan dL dengan menggunakan signifikansi 5\%, sebesar 1,651 dan 1,258. Oleh karena itu DW sebesar 2,083 > du dan kurang dari (4-du) 4-1,651 = 2,349 maka dapat disimpulkan tidak terjadi autokorelasi baik positif maupun negatif.

\section{Koefisien Determinasi (R square)}

Tabel 6. Koefisien determinasi

\begin{tabular}{|l|c|r|r|c|}
\hline Model & R & R Square & Adjusted R Square & Std. Error \\
\hline 1 & $0.421^{\mathrm{a}}$ & 0.177 & 0.092 & 0.0439004062 \\
\hline \multicolumn{2}{|l}{ a. Predictors: (Constant), Kinerja Lingkungan, Kepemilikan } \\
Institusional, Profitabilitas
\end{tabular}

Pada table 6. menunjukkan nilai $\mathrm{R}$ square sebesar 0,177 . Hal ini menunjukkan bahwa pengaruh variabel independen yaitu: profitabilitas, kepemilikan saham dan kinerja lingkungan dapat menjelaskan pengungkapan ISR sebesar $17,7 \%$. Selebihnya $82,3 \%$ dipengaruhi oleh faktor lain diluar penelitian.

\section{Hasil Uji F Statistik}

\section{Tabel 7. Hasil Uji F Statistik}

\begin{tabular}{|l|c|c|c|c|c|}
\hline \multicolumn{1}{|c|}{ Model } & Sum of Squares & $\boldsymbol{d f}$ & Mean Square & F & Sig. \\
\hline Regression & 0.012 & 3 & 0.004 & 2.086 & $0.124^{\mathrm{b}}$ \\
\hline Residual & 0.056 & 29 & 0.002 & & \\
\hline Total & 0.068 & 32 & & & \\
\hline
\end{tabular}

Tabel 7 diketahui nilai uji $\mathrm{F}$ adalah 2,086 dengan nilai signifikansi yaitu 0.124>0.05. Hal ini menunjukkan bahwa variabel kinerja lingkungan, kepemilikan institusional dan profitabilitas secara simultan mampu menjelaskan pengaruhnya terhadap variabel ISR. Model regresi tidak memenuhi model fit. 


\section{Hasil Uji t (Hipotesis)}

\section{Tabel 8. Hasil Uji t}

\begin{tabular}{|l|c|c|c|c|c|}
\hline \multirow{2}{*}{ Variabel } & \multicolumn{2}{|c|}{ Unstandardized Coefficients } & Standardized Coefficients & \multirow{2}{*}{ t } & \multirow{2}{*}{ Sig. } \\
\cline { 2 - 5 } & $\mathrm{B}$ & Std. Error & Beta & & \\
\hline (Constant) & 1.080 & 0.210 & & 5.151 & 0.000 \\
\hline Profitabilitas & 0.793 & 0.411 & 0.419 & 1.931 & 0.063 \\
\hline Kepemilikan Institusional & -0.005 & 0.002 & -0.497 & -2.296 & 0.029 \\
\hline Kinerja Lingkungan & 0.083 & 0.076 & 0.187 & 1.095 & 0.282 \\
\hline
\end{tabular}

\section{Pengujian Hipotesis 1}

Profitabilitas berpengaruh terhadap ISR

Dari tabel t-hitung sub struktur 2 dapat dilihat bahwa profitabilits memiliki nilai t-hitung $(1,931)<\mathrm{t}$-tabel $(2,042)$ dengan nilai signifikansi $0,063>0,05$ dan nilai koefisien $\beta$ positif yaitu 0,419 . Hal ini menunjukkan bahwa variabel profitabilitas (X1) tidak berpengaruh terhadap ISR (Y), dan kesimpulannya hipotesis 1 ditolak. Hasil ini selaras dengan penelitian Haniffa (2002) yang menyatakan bahwa dalam pandangan Islam, perusahaan yang memiliki niat untuk melakukan pengungkapan. Perusahaan tetap mengungkapkan Islamic Social Reporting terlepas dari tinggi atau rendahnya profit yang mereka miliki.

Hal ini dikarenakan perusahaan memandang pengungkapan Islamic social reporting sebagai suatu kebutuhan. Perusahaan menyadari bahwa pengungkapan Islamic social reporting sangat penting sebagai wujud transparansi perusahaan untuk dapat menambah kepercayaan serta nilai perusahaan dimata para pengguna laporan. Hasil penelitian ini konsisten dengan Astuti (2014) dan Iwan (2015) menemukan bahwa profitabilitas perusahaan tidak berpengaruh terhadap pengungkapan Islamic social reporting. Hal tersebut bertolak belakang dengan Lestari (2013) yang menyatakan bahwa tingkat profitabilitas berpengaruh signifikan terhadap pengungkapan ISR. Hal ini menggambarkan suatu perusahaan ketika perusahaan memiliki laba yang tinggi berarti perusahaan menganggap tidak perlu mengungkapkan informasi yang dapat mengganggu kesuksesan tersebut, yaitu pencapaian laba.

\section{Pengujian Hipotesis 2}

Kepemilikan Institusional berpengaruh terhadap ISR.

Kepemilikan institusional yaitu jumlah saham yang dimiliki oleh suatu institusi dalam perusahaan. Kepemilikan institusional diukur dengan presentase jumlah saham milik institusi terhadap jumlah saham yang beredar dalam perusahaan (Hastuti, 2011). Dari hasil tabel t-hitung sub struktur 2 terlihat bahwa kepemilikan institusional mempunyai nilai sig 0,029<0,05 dengan nilai koefisien $\beta$ negative yaitu -0,497. Dari hasil tersebut dapat disimpulkan bahwa kepemilikan institusional berpengaruh negatif terhadap ISR dan hipotesis 2 diterima. Hasil penelitian ini sesuai dengan Rahman (2012) bahwa kepemilikan institusional berpengaruh terhadap pengungkapan tanggung jawab sosial perusahaan. Murwaningsari (2009) menyatakan bahwa institusional shareholders dengan kepemilikan saham yang besar, memiliki insentif untuk memantau pengambilan keputusan perusahaan. Apabila dikaitkan dengan pengungkapan tanggung 
jawab sosial, aktivitas monitoring yang dilakukan oleh investor institusi dapat memaksa manajemen untuk mengungkapkan informasi sosialnya.

Hariyanti (2012) menyatakan bahwa perusahaan dengan kepemilikan institusional yang besar lebih mampu untuk memonitor kinerja manajemen. Investor institusional memiliki power dan experience serta bertanggung jawab dalam menerapkan prinsip good corporate governance untuk melindungi hak dan kepentingan seluruh penegang saham sehingga mereka menuntut perusahaan untuk melakukan komunikasi secara transparan. Dengan demikian, kepemilikan institusional dapat meningkatkan kualitas dan kuantitas pengungkapan secara sukarela, hal ini berarti kepemilikan institusional dapat mendorong perusahaan untuk meningkatkan pengungkapan tanggung jawab sosial dan lingkungan.

\section{Pengujian Hipotesis 3}

Kinerja Lingkungan berpengaruh terhadap ISR.

Dari tabel t-hitung sub struktur 2 dapat dilihat bahwa kinerja lingkungan memiliki nilai signifikansi $0.282>0,05$ dan nilai koefisien $\beta$ positif yaitu 0,187 . Hal ini menunjukkan bahwa variabel kinerja lingkungan (X3) tidak berpengaruh terhadap ISR (Y), dan kesimpulannya hipotesis 3 ditolak. Hasil penelitian ini sesuai dengan Verawaty, dkk (2016) yang menyatakan bahwa kinerja lingkungan tidak memiliki pengaruh terhadap pengungkapan Islamic Social Reporting (ISR).

Hasil penelitian bertolak belakang dengan Amran dan Devi (2008) dalam Putri (2014) yang menyatakan bahwa perusahaan yang memiliki kondisi keuangan yang kuat, juga akan mendapatkan tekanan yang lebih dari pihak eksternal perusahaan untuk lebih mengungkapkan pertanggung jawaban sosialnya secara luas. Suatu perusahaan yang memiliki profit lebih besar harus lebih aktif melaksanakan tanggung jawab sosialnya.

\section{Kesimpulan}

Penelitian ini bertujuan untuk menguji pengaruh profitabilitas, tipe kepemilikan institusional, dan kinerja lingkungan Bank Umum Syariah terhadap pengungkapan Islamic Social Reporting (ISR) pada perbankan syariah di Indonesia.Berdasarkan hasil penelitian dan pembahasan, maka dapat disimpulkan sebagai berikut:

1. Profitabilitas tidak berpengaruh terhadap pengungkapan Islamic Social Reporting (ISR).

2. Kepemilikan institusional berpengaruh terhadap pengungkapan Islamic Social Reporting (ISR).

3. Kinerja lingkungan berpengaruh terhadap pengungkapan Islamic Social Reporting (ISR). 


\section{DAFTAR PUSTAKA}

Amran, Azlan dan S. Susela Devi.(2008). "The Impact Of Government And Foreign Affiliate Influence On Corporate Social Reporting (The Case Of Malaysia)".Accounting, Auditing and Accountability Journal, Vol. 23, No. 4, hal. 386-404

Astuti, Tri Puji. 2014. Faktor - Faktor Yang Mempengaruhi Pengungkapan Islamic Social Reporting (ISR) pada Bank Syariah Indonesia. -XUQDO Universitas Muhammadiyah Surakarta.

Deegan, C. 2000. Financial Accounting Theory. NSW: McGraw-Hill Australia.

Dusuki, A.W. 2005. Corporate Social Responsibility of Islamic Banks in Malaysia: A Synthesis of Islamic and Stakeholders' Perspectives. Tesis Fakultas Ekonomi Loughborough University.Inggris.

Eden, C. and Ackermann, F. (1998), Making Strategy: The Journey of Strategic Management, Sage Publications, London.

Farook, S. Z., \& Lanis, R. 2003.Banking on Islam? Determinants of CSR Disclosure.International Conference on Islamic Economics and Finance.

Freeman, R.E. (1984), Strategic Management: a Stakeholder Approach, Pitman, Boston, MA. Haniffa, R., 2002, "Social Reporting Disclosure-An Islamic Perspective”, Indonesian Management \& Accounting Research 1(2), pp.128-146

Hastuti, Yenny Widya. 2011. "Pengaruh Mekanisme Corporate Governance Secara Internal dan Eksternal Terhadap Kinerja Keuangan : Studi Kasus di Bank yang Terdaftar di BEI 20062009”. Skripsi. Semarang: Universitas Diponegoro.

Iwan, Setiawan. 2015. Faktor-faktor yang Memengaruhi Islamic Social Reporting (ISR) pada Bank Syariah di Indonesia. Skripsi.Institut Agama Islam Negeri Antasari.Banjarmasin.

Jensen, M.C. and Meckling, W.H. (1976), “Theory of the Firm: Managerial Behavior, Agency Costs and Ownership Structure”, Journal of Financial Economics, Vol. 3, pp. 305-360.

Khairunnisa.(2010). Analisa Perbandingan Rasio Keuangan Bank Syariah Sebelum dan Sesudah Menerapkan Corporate Social Responsibility (CSR).Skripsi, UIN Syarif Hidayatullah, Jakarta

Lestari, Puji. (2013). Determinants of Islamic Social Reporting In Syariah Banks: Case of Indonesia. International Journal of Business and Management Invention, 2(10), 28-34.

Maali, B., Casson, P., Napier, C. (2006). Social Reporting by Islamic Banks.ABACUS, 42 (2), pp 266-289. 
Maulida, A. P., Yulianto, A., Asrori. (2014). Analisis Faktor-Faktor yang Mempengaruhi Pengungkapan Islamic Social Reporting (ISR).SNA 17 Mataram.Lombok. Universitas Mataram.

Murwaningsari, Etty. 2009. Hubungan Corporate Governance, Corporate Social Responsibilities dan Corporate Financial Performance Dalam Satu Continuum. Jurnal Akuntansi Dan Keuangan. Vol. 11, No. 1, Mei 2009: 30-41 Jakarta: Universitas Trisakti.

Othman, R, Thani, A.M., \& Ghani, E. K. 2009.Determinants of Islamic Social Reporting Among Top Sharia-Approved Companies in Bursa Malaysia.Research Journal of International Studies, 12, 4-20.

Raditya, A. N. (2012). Analisis Faktor-Faktor Yang Mempengaruhi Pengungkapan Islamic Social Reporting (ISR) Pada Perusahaan Yang Masuk Daftar Efek Syariah (DES). Skripsi, Universitas Indonesia, Depok.

Rahman, Arif. 2011. "The Effect of Good Corporate Governance Indicators (GCG) Toward Disclosure of Corporate Social Responsibility (CSR) in Manufacturing Companies Listed in Indonesia Stock Exchange Period 2008-2010.

Sujarweni, V. Wiratna. 2014. SPSS untuk Penelitian. Pustaka Baru Press: Yogyakarta.

Verawaty, Darmawan, J., Kariza, A., (2016). Determinan Pengungkapan Islamic Social Reporting Pada Perusahaan Yang Terdaftar di Jakarta Islamic Index. ISSN: 23032235. Vol. 4, No. 1, Januari - Juni 2016.

Watts, R. L., \& Zimmerman, J. L. (1986).Positive Accounting Theory. USA: Prentice-Hall.

Widiawati, S. dan Raharja S. (2012).Analisis Faktor-Faktor Yang Mempengaruhi Islamic Social Reporting Perusahaan-Perusahaan Yang Terdapat Pada Daftar Efek Syariah Tahun 20092011. Diponegoro Journal of Accounting 1(1), 1-15. 